\title{
The implications of the book of Acts 8:1-8 for the Nigerian Church
}

\author{
Adenigba Olatayo Stephen \\ Department of Pastoral Studies, ECWA Theological Seminary \\ Igbaja, Kwara State, Nigeria \\ Adenigbatayostephen@gmail.com \\ Kolawole Oladotun Paul \\ Department of Religious Studies, Olabisi Onabanjo University \\ Ago-Iwoye, Nigeria \\ Pauldotun98@gmail.com
}

DOI:https://doi.org/10.46222/pharosjot.10210

\begin{abstract}
During the early centuries CE of the Church, it was characterized by trials, contempt of the faithful and persecutions. Christians who were unwilling to compromise their faith were martyred in the process in the most terrible ways. The rationale behind this study is to focus on Christian persecution, especially beginning from the biblical context; in order to examine what Christian persecution is all about and what it is not. This research thus briefly examines the issue of persecution in the early Church with specific attention to Acts 8:1-8. An exegetical and descriptive methodology is explored in this research. The contemporary state of Nigeria is reflected the early church. This research not only discusses the issue of persecution in the early church, but also analyzes and places it side by side with such happenings in the nation of Nigeria today. In view of this, the contemporary Christians in Nigeria do and may in future also benefit a great deal from the early Church's experience.
\end{abstract}

Keywords: Acts, Church, Christians, Nigeria, Persecution.

\section{Introduction}

Although Christians today enjoy greater religious freedom in many countries, persecution remains a fact in several places in the world. Accounts of Christian persecution are found in the New Testament. ${ }^{1}$ One of the first Christian martyrs was Stephen, a member of the early church brought before the Sanhedrin, the assembly of Jewish religious leaders, on charges of blasphemy. Stephen was subsequently stoned, touching off a mass persecution of Christians led by Saul of Tarsus. After claiming to have received a vision of Jesus in the clouds, Saul changed his name to Paul and became a convert to Christianity. His new faith would subject him to various imprisonments and beatings, some of which he recounted in New Testament writings. ${ }^{2}$ This study is designed to educate Christians (especially in Nigeria) on the issue of persecution and its effects on the spread of Christianity. An exegetical and descriptive methodology has been briefly explored in the Nigerian context.

\footnotetext{
${ }^{1}$ W.H.C. Frend, Martyrdom and Persecution in the Early Church (Oxford: Blackwell, 1965), 514.

${ }^{2}$ Paul Marshall and Lela Gilbert, Their Blood Cries Out: Persecution in View (Illinois: Word Press, 1997$), 87$.
} 
Christian persecution can be traced from the first century of the Christian era to the present day. Early Christians were persecuted for their faith by Jews from whose religion Christianity arose, and Romans who controlled many of the lands across which early Christianity was spread. $^{3}$ In Nigeria, as well as many other parts of Africa with significant Muslim populations, the persecution of Christians has long been familiar. Many Christians have been murdered in Nigeria by either militant Fulani herdsmen or Boko Haram. ${ }^{4}$ Initially, these conflicts were considered "communal conflicts," but the organization of the attacks by the Fulani herdsmen has pressed the conflict beyond land grabbing.

Since 2016, some estimate that militant Fulani herders have killed more than 500 Christians in Nigeria. ${ }^{5}$ In some northern states, increasing numbers of Christians are dressing like Muslims to make their faith less obvious and reduce the chances of attack. Young people who are Christians in these states are frequently denied access and even asked to give up their faith in order to be given work.

\section{Background of Acts 8:1-8}

The book of Acts focus is clearly on some of the acts or deeds of mostly Peter (the key figure in the first half) and Paul (the key figure in the second). Though he does not mention himself by name, the author is undoubtedly Luke, physician and frequent traveling companion of the apostle Paul. Luke is described as "the beloved Physician" (Colossians 4:14), and the vocabulary of both the gospel and Acts shows evidence of a medical mind. ${ }^{6}$ Mentioned as a "fellow laborer" (Philippians 24) who was with Paul in his last days (2 Timothy 4:11), Luke often accompanied Paul on his travels beginning with his second journey.

It is evident Luke was very careful to provide a historically accurate account in the both the gospel and Acts (Lk 1:1-4, 5; 2:1-3; 3:1-2). Luke is a historian of the first rank; not merely are his statements of fact trustworthy, he is possessed of the true historic sense. This author should be placed along with the greatest of historians." In fact, Luke provides the only record of the first thirty years of the early church. Both the gospel and Acts were written to one man: Theophilus (Luke 1:3; Ac 1:1), whose name means "God lover".

Ramsay suggests the use of "most excellent" (Luke 1:3) was a title like "Your Excellency" (Acts 23:26; 26:25) and that Theophilus was a government official of high rank. ${ }^{7}$ It is not used in Acts $(1: 1)$, and one intriguing possibility is that he became a believer in between receiving the gospel and Acts. ${ }^{8}$ The book ends abruptly with Paul placed under house-arrest and awaiting trial in Rome (28:16,30-31). This may indicate that the book was written before Paul's trial and eventual release. The dates for Paul's first imprisonment in Rome are 60-62 CE If the book was just before

\footnotetext{
${ }^{3}$ P. C. Scales, Influence of Persecution (Westerville, OH: National Middle School Association, 2010 ), 67.

4 B. Casey, The Continuing Persecution of Nigerian Christians https://erlc.com/resource-library/articles/thecontinuing-persecution-of-nigerian-christians (Accessed on 18th June, 2019).

${ }^{5}$ Casey, The Continuing Persecution of Nigerian Christian.

${ }^{6}$ K. Roney, The Book of Acts with a Spectacle (Greenwich, CT: Information Age, 2005), 96.

${ }^{7}$ Ann Benton, Paul, the Persecutor of the Church: Acts (Norton Street: Inter-Varsity Press, 2009$), 76$.

Some have entertained the possibility that Theophilus was a Roman official in charge of administering Paul's case before Caesar, and that the gospel and Acts were written to help him understand the facts of Jesus Christ and Paul's role in the history of the church.

${ }^{8}$ Roney, 97.
} 
or after Paul's release, then it was likely written around $63 \mathrm{CE}$. from Rome. ${ }^{9}$ The book begins in Jerusalem and ends in Rome. ${ }^{10}$

\section{Purpose of the book}

The Acts narrative is considered to be a missionary document. The Lukan purpose can be classified thus:

1. To assure his Christian audience of the truthfulness of what they had come to believe.

2. To clarify their understanding of their relationship with Israel.

3. To correct the understanding of Christian concern about the parousia.

4. To provide an apologetic work for both Christians and non-Christians. ${ }^{11}$

\section{Structure of Acts 8:1-8}

Acts 8:1-8 is the main passage which begins with reference to the great persecution that broke out against the Jerusalem Church following the death of Stephen. Luke reveals the mysterious figure, Saul, as the chief proponent of the persecution. Tensions between the Church and the Jewish leadership appear to be at the crux of the passage. ${ }^{12}$ The events by Luke indicates that the Church is an oppressed minority in Jerusalem, lacking any form of political power base and are victims of the violent dispositions of the largely hostile Jewish majority in the city. ${ }^{13}$ The reference to Samaria in the text is a window into the Jew-Samaritan relations, which was mostly hostile especially concerning their respective holy sites.

While the Acts narrative is intended for Theophilus, it is likely that through the narrative of LukeActs, the author is attempting to convince and influence literate gentile readers and leaders of society, as part of Luke's persuasive rhetoric to the early Christian movement in the first century or early second century. Thus, Luke is addressing the concerns, questions, and confusions of the Jews of the day, regarding the substance of their beliefs and nature of the Christian community. ${ }^{14}$ In the larger context of the narrative, the passage may be shown to be within the

\footnotetext{
${ }^{9}$ J. J. Arnett, The Acts of the Apostles in the Early Church: Exposition (Upper Saddle River, NJ: Prentice Hall, 2010), 78.

${ }^{10}$ It describes the establishment and growth of the Lord's church throughout the Mediterranean world through the work of the apostles and other Christians under the direction of the Holy Spirit.

${ }^{11}$ Ajith. Fernando, The NIV Application Commentary: Acts (Grand Rapids, MI: Zondervan Publishing House, 1998), 23.Also, the spread of the gospel across geographical boundaries and human barriers is a dominant idea runs through the narrative. The place of suffering on account of opposition to the gospel in the life of the church and the sovereignty of God in suffering are notable themes; in fact this is of direct relevance to Acts 8:1-8.

Michael Carl Parsons, Acts (Grand Rapids, Michigan: Baker Academic, 2008), 23.

${ }^{12}$ Kingsley Barrett and A. Charles, Critical and Exegetical Commentary on the Acts of the Apostles (Edinburgh: T \& T Clark, 1994), 67.

The text is also located in the context of hostile Jewish sentiment regarding the Church, which manifests itself in the form of violent opposition, including the killing of believers, resulting in displacement and scattering of the believing community.

${ }^{13}$ Barrett, 69.

${ }^{14}$ C.S. Keener, The IVP Bible Background Commentary 2nd ed. (Downers Grove, IL: InterVarsity Press, n.d), 89.
} 
second part of the three-part structure of Acts, which marks the extension of missions to Judea and Samaria. In fact, Acts $8: 1 \mathrm{~b}$ could be identified as the starting point of this mission. ${ }^{15}$

Acts 8 is a key passage, which marks the introduction of Saul, soon to be, Paul, the missionary to the Gentiles and the key figure of the second part of the Acts discourse. The Samaritan episode of Acts 8 appears as a great significance to the Acts 1:8 programme. Acts 8 serves as link between mission in Jerusalem and mission to the world. Somewhat of an in-between or middle point of this journey, Acts 8, emerges as the halfway stage of this movement of the gospel to Rome and to the ends of the world. ${ }^{16}$

\section{Analysis of the texts}

Acts 8:1-3 gives the details of persecution in Jerusalem perpetrated by the Sanhedrin and Jewish people. Then, verses 4-8 showcase the consequences of this persecution which reverberates across to Samaria by way of the journeying of the scattered community. ${ }^{17}$ A contrast of experience also appears in terms of the well-being of the church. While destruction is the fate of the church in Jerusalem, a new experience in the gospel befalls Samaria and Judea such that the Apostles were scattered about it.

Firstly, Luke draws the attention of the readers' to the intensity of the persecution, stating that a great persecution broke out in Jerusalem following the martyrdom of Stephen (vs. 1). Luke adds here that the apostles remain back in Jerusalem, while the rest disperse from the city. This is indicative of the fact that the attacks and violence, perhaps, was aimed at Hellenistic-Jews that were closely identified with Stephen and not the whole church per se. ${ }^{18}$ Despite the tensions in the city, the apostles chose to stay back in order to hold the church's 'fort' in Jerusalem. Luke could also be making an effort here to highlight the virtues of the church leaders in terms of their courage and perseverance. ${ }^{19}$

The dispersion of the believers is not planned on the part of the church community. It rather appears to be a swift reaction to the escalation of hostilities in Jerusalem. Up until this point, the church Jerusalem had experience persecution, however, of a lesser intensity. ${ }^{20}$ Luke provides the readers insight into the characteristics of those performing the burial of Stephen. ${ }^{21}$ The actions of the godly men, possibly friends of Stephen, disregarding the law to mourn for him, is not only a

${ }^{15}$ Frank E. Gaebelein, The Expositor's Bible Commentary, Volume 9 (John-Acts) (Grand Rapids, Mi.: Regency Reference Library, 1981), 56.

${ }^{16}$ Michael White, The Church: From Jesus to Christianity (New York: Harper-Collins, 2004), 76.

${ }^{17}$ Howard I. Marshall, Acts of Apostles (Nottingham: Inter-Varsity Press, 2008), 78. Donald J. Guthrie, A Motyer, A.M. Stibbs, and D. J. Wiseman, The New Bible Commentary (London: The Inter-varsity Press, 1970$), 67$.

${ }^{18}$ Darrell L. Bock, Acts (Grand Rapids, Mich.: Baker Academic, 2007), 32.

${ }^{19}$ Robert L. Gallagher and Hertig Paul, Mission in Acts (Maryknoll, N.Y.: Orbis Books, 2007), 34. Notably, the threefold structure of the Acts narrative also emerges in this single verse. While the apostles tend to Jerusalem, the believing community, possibly, mostly, Hellenized Jews, disperse throughout Palestine.

${ }^{20}$ Craig S. Keener, Acts (Grand Rapids, Mich.: Baker Academic, 2013), 123.

${ }^{21}$ The intensity of the experience of the men, stating that they mourned deeply for him. While it was normal to bury executed criminals, Jewish law prohibited mourning publicly for a condemned criminal. N. R. Needham, Years of Christ's Power (Part one): The Age of the Early Church Fathers (Durham, England: Evangelical Press, 1997), 49.Elwell, A. Walter, Theology of the Church (Michigan: Baker Books House, 1984), 320. 
showcase of defiance and courage but also an insight into the character of Stephen, which warranted a show of such honor on the part of these men. ${ }^{22}$

Furthermore, Saul, the chief proponent of the persecution is introduced. Luke's reference here that women, as well as men, were put in prison, portrays the intensity and ferocity of Saul's action, which is likely to have been more zealous and vicious than most of his contemporaries. The reference could also serve Luke's concern for women, highlighting the courage and faithfulness of the women disciples. Here, Luke appears to place women and men as equal members of the Church, since they are equally offensive to persecutors. Saul going from house to house is indicative of targeted, mass scale mob violence against the Christian community in Jerusalem. The hostilities resulted in severe economic consequences for the believing community; perhaps, some Judeans could have also lost property during the persecution, increasing the Church's poverty. ${ }^{23}$ The abrupt identification of Saul could be interpreted as an assurance given by Luke to his readers that the very forces that undermine the church could turn to becoming champions of the cause. Although seemingly absent in the narrative, underneath the storyline, Luke appears to be bearing witness to the sovereignty of God over the Church, affirming to his readers that the purposes of God could not be thwarted, despite the intense persecution experienced by the people of God. ${ }^{24}$

The fourth verse marks a geographical shift from Jerusalem to the believing community in the dispersion. While the persecution forced the believers to flee their homes and hometown, Luke highlights the missionary-status of the fleeing community, adding that they preached the word wherever they went. The negative experience of believers in Jerusalem is seemingly redefined by Luke, who attributes to the fleeing community a sense of greater purpose and positivity of experience, as bearers of the gospel in the dispersion. ${ }^{25}$

Luke then zooms out of the community of believers to Philip and his mission in Samaria. While the region of Samaria was not necessarily perceived as Gentile territory, owing to the Samaritans being viewed as those on the margins of Judaism, it nevertheless, marked the movement of the gospel away from Jerusalem to its rival town. However, Luke narrates the Samarian mission as a bridge, which sets the stage for Gentile outreach. ${ }^{26 “ . . . P h i l i p ~ w e n t ~ d o w n ~ t o ~ a n ~ u n n a m e d ~ c i t y ~ i n ~}$ Samaria, and proclaimed the Messiah there"; this event depicts a sense of deliberateness on the part of Philip in undertaking the mission to Samaria. The success of Philip's mission is explored in the succeeding verse, stating that he performed signs, which attracted the attention of the Samarians. ${ }^{27}$ Even in verse 7, details is give concerning miracles and signs performed by Philip The presence of signs in Philip's mission, which accompanies the preaching of the Messiah, indicates of the approval of God for the ministry. Here, the narrative bears testimony to the sovereignty of God in the larger scheme of affairs, directing and governing the life and destiny of

\footnotetext{
22 J.P.K. Andrew, The History of the Church in Acts (New York, Apollo Place: Inter varsity Press, 1989 ), 218.

${ }^{23}$ S. Hodder, The Illustrated Bible Dictionary, Part 3 (Michigan: Intervarsity Press, 1980), 89.

${ }^{24}$ Peter Dark, Interpretation of Tongues in the Church of our Days (Wheaton, Illinois: Tyndale House Publishers, 1999), 1912.

25 Michael Green, I believe in the Holy Spirit: Acts of Apostles (Grand Rapids: Williams Erdmann Publishing Company, 1975), 11.

${ }^{26}$ B. Malcolm, Acts of Apostles: Understanding Sections of the Book (New York: H and R Books, 1999$), 72$.

${ }^{27}$ Signs and wonders, which complemented teaching and preaching in Luke-Acts is an upshot of the activity of the Holy Spirit.
} 
the believing community even through the unconventional means of persecution and violence and subsequent dispersions. ${ }^{28}$

The eighth verse is a summary of the whole episode, stating that there was great joy in that city. Joy is a notable feature of conversion in Luke-Acts. ${ }^{29}$ As such, it appears that Luke is clearly making reference to the fact that the persecution in Jerusalem and dispersion across Palestine had served in the effective expansion of the gospel in the region. In other words, death and destruction transpired to bring the gospel to life elsewhere.$^{30}$ Over-all, the analyzed text begins with great lamentation over Stephen's death, but later culminates with great joy experienced by the believers in a city in Samaria. ${ }^{31}$ In view of this, Acts 8:1-8 as explicated in this article bears testimony to the overarching truth that the mission of God cannot be thwarted. In fact, persecution appears to serve the divine purposes, in achieving the mission of God. The devastation of the community of believers in Jerusalem had been used as a means to create new communities of believers elsewhere.

\section{Relevance of Acts 8:1-8 for Nigerian Christians}

While persecution seemingly brings disaster, it is nevertheless a phenomenon that lies within the sovereignty of God as seen in the analyzed text. From the text, the early Church what contemporary Christians will call a 'non-violent approach' to persecution; evidently, prevents the "poison of hatred" to spread, thus paving the way for effective mission efforts. Persecution is a double-edged sword; while it could bring about an extension of the church, as evidenced in Samaria and across Judea as a result of the dispersion caused by the greater Jerusalem persecution, it could also bring about the destruction of the church as evidenced in Jerusalem and, in particular, the demise of Stephen the protomartyr who died by stoning.

Persecution does not define the destiny of the church; but God does. This is a crucial exhortation that needs to be made to persecuted believers, urging Christians to bask in and embrace the sovereignty of God, especially in times of suffering, remembering that God determines their destiny and not their persecutors -whether the State, an extremist group, members of family, or even the wider community. Nicolaides $(2010 ; 2015)$ asserts we are the church, the creation of the Ekklesia by the incarnate logos of God created in a new and unique relationship as God's people that allows humanity to enter into the Covenant and to become part of the 'people of God' (Laos tou Theou) and are likely to be persecuted. and in this relationship gender equity, for one, is important to positively promote. Like in the first century CE Palestine, often, even today, prominent figures direct the persecution of Christians; with the intervention of God, such characters could be transformed to become champions in the vineyard of Christ. Therefore, Christians in Nigerian should unceasingly pray for these personalities, that God would meet them and transform them. The common conduct of the dispersing community was that they preached the word of God. Persecution could distract believers from ministering the gospel; this should not happen. Preaching through persecution is a key factor that determines the effectiveness of believing community in times of trials. Church in Nigeria though persecuted shouldn't trade the good news for anything; the platforms for dishing God's word must be echoed often and often again. Also,

\footnotetext{
${ }^{28}$ George Otis, The Last of the Giants (Grand Rapids, MI: Chosen Books, 3 1991), 261-264.

${ }^{29}$ Samuel Whitefield, Moving Towards a Biblical Understanding of Persecution (Grand Rapids, 2004), 23.

${ }^{30}$ Hodder, The Illustrated Bible Dictionary, 89.

${ }^{31}$ D. Elkind, The Story of the Early Church: Exposition on Acts 8:1-15 (New York, NY: Oxford University Press, 1981), 2.
} 
the cooperation of the Church is cardinal to the manifestation of God's glory like he has done during the days of the Apostles.

The experience of the believing community in the analyzed text is in stark contrast to the prosperity Gospel in Nigerian context. The gospel of Jesus Christ invariably brings contention and struggles in a hostile world. There is a pressing need to today to equip the contemporary church with regard to the theology of suffering and prepare believers to face persecution. When a Christian loses anything for the sake of Christ he will be in a position to receive much more than what he left behind. Jesus himself promises, there is no one who has left house or brothers or sisters or father or mother or wife or children or lands, for my sake and the gospel's, who shall not receive a hundredfold now in this time, houses and brothers and sisters and mothers and children and lands, with persecutions and in the age to come, eternal life" (Mark 10:29-30).

There is need for the Nigerian Church to pray to God to manifest himself in the course of the outraging persecution; the sphere of the prayer can also be geared in a dimension that God should grant Nigerian believers boldness and courage to continue the great command given by Jesus Christ (Matthew 28:19-20); this was explicitly the reaction of Philip after the death of Stephen which was a result of persecution of Christians in the early church.

The Nigerian Church needs to pray to God such that gospel preaching are back with miracles and signs which cannot be disproved but rather stir convictions about Jesus Christ and one's faith. This stance does not entail cooked-up or arranged miracles, which is a common phenomenon in the recent time. ${ }^{32}$

\section{Conclusion}

Seldom would one encounter any believer whose death wish is to be thrown into the mouth of hungry lions. These are nightmarish scenes that many of the martyrs in the early church actually experienced. Luke unequivocally communicates the truth that God is sovereign over persecution and the church. On this note, this article concludes that God uses persecution as a means to fulfill his purposes and will. When persecution is going on believers are not mere victims in the hands of powerful persecutors and opponents; but rather, enveloped in the safe and sovereign hands of God. This is to say that persecution does not thwart the purposes of God; but serves the divine will to activate the community of believers for the mission of God or fulfill greater purposes in the kingdom of God. This is evidenced by the missionary status granted by Luke to the believing community in dispersion and the success credited to Philip's pioneering mission in Samaria. Not

\footnotetext{
${ }^{32}$ Fake miracles is trending in the Nigeria media about the Church. Several instances of ministers faking miracles in their so called 'prayer programs' have been spotted. For example; A report on Gist Online News 24th November, 2016 gives an account of a man who allegedly dies during fake miracle. The man of God in question had paid the man who is a trader, the sum of N500, 000 to pretend to be dead and to be carried in a coffin to the venue of a crusade where the pastor would perform the fake miracle and allegedly raise him from the dead. But before the coffin could get to the venue of the event, the trader had reportedly died probably due to suffocation.

According to Punch Online News on 25th of October, 2019; "Pastors come under fire for alleged stage-managed miracles": the founder of Mountain of Liberation and Miracle Ministry, aka Liberation City, Dr Chris Okafor, has come under fire on social media after a video clip showing him performing what appeared like a miracle created a controversy. However, the same woman was shown in another video clip claiming she had the same problem as another unidentified pastor prayed for her in the public.

Oladotun Paul Kolawole, "God Will Supply All Your Needs According to His Glorious Riches: The Problem of Extreme Materialism among Nigerian Pastors",Crucible Journal of Theology and Ministry,11:1 (2020), 4.
} 
many Christians would gladly embrace the torture that is involved in being tied to a stake or relish being consumed by leaping tongues of fire amidst a jeering crowd of onlookers.

Persecution is dangerous and could spell disaster for communities of believers. Accordingly, it is important to take all steps necessary to pray for, teach, disciple, and safeguard vulnerable communities, serving on the frontlines of persecution. A proper understanding of the eschatological realities that persecution is an experience the Church cannot but have leaves no one in doubt that Nigerian Christians would pass through more trials, which the early church experienced, before the second coming of Christ.

\section{References}

Agnes, S. (2014). The Triage of the Church in the Face of Persecution: An Historical Appraisal. Ghana: Alvins Press.

Alvins, H. (1999). The Unity: Church and Its Components. London: Harper and Row Publishing Company.

Andrew, J.P.K. (1989). The History of the Church in Acts. New York, Apollo Place: Inter varsity Press.

Arnett, J.J. (2010). The Acts of the Apostles in the Early Church: Exposition. Upper Saddle River, NJ: Prentice Hall.

Barrett, K. \& Charles, A. (1994). Critical and Exegetical Commentary on the Acts of the Apostles. Edinburgh: T \& T Clark.

Benton, A. (2009). Paul, the Persecutor of the Church: Acts. Norton Street: Inter-Varsity Press.

Bock, D. L. (2007). Acts. Grand Rapids, Mich.: Baker Academic.

Dupon, J. (1964). The Source of Acts: The Present Position in the Nigerian Church. New Jersey, Prentice Hall.

Elkind, D. (1981). The Story of the Early Church: Exposition on Acts 8:1-15. New York, NY: Oxford University Press.

Fernando, A. (1998). The NIV Application Commentary: Acts. Grand Rapids, MI: Zondervan Publishing House.

Gaebelein, F. E. (1981). The Expositor's Bible Commentary, Volume 9: John-Acts. Grand Rapids, Mi.: Regency Reference Library.

Gallagher R. L. \& Paul, H. (2007). Mission in Acts. Maryknoll, N.Y.: Orbis Books.

Gilligan, C. (1982). Exposition of the Book of Acts. Cambridge, MA: Harvard University Press.

Green, M. (1975).I believe in the Holy Spirit: Acts of Apostles. Grand Rapids: Williams Erdmann Publishing Company, 1975. 
Guthrie, D., Motyer, J.A., Stibbs, A.M. \& Wiseman, D.J. (1970). The New Bible Commentary. London: The Inter-varsity Press.

Hodder, S. (1980). The Illustrated Bible Dictionary. Michigan: Intervarsity Press.

Keener, C. S. (2013).Acts. Grand Rapids, Mich.: Baker Academic.

Keener, C. S. (2014). The IVP Bible Background Commentary 2nd ed. Downers Grove, IL: InterVarsity Press.

Malcolm, B. (1999). Acts of Apostles: Understanding Several Sections of the Book. New York: H and $\mathrm{R}$ Books.

Marshall, H.I. (2008). Acts of Apostles. Nottingham: InterVarsity Press.

Nicolaides, A. (2015). Gender equity, ethics and feminism: Assumptions of an African Ubuntu Oriented Society, Journal of Social Science, 42(3), 191-210.

https://doi.org/10.1080/09718923.2015.11893407

Nicolaides, A. (2010). 'The Laos tou Theou - an orthodox view of the "people of God"', HTS Teologiese Studies/Theological Studies, 66(1), DOI:10.4102/hts.v66i1.372

Oladotun Paul Kolawole. (2020).God Will Supply All Your Needs According to His Glorious Riches: The Problem of Extreme Materialism among Nigerian Pastors, Crucible Journal of Theology and Ministry,11(1), 4.

Otis, G. (1991). The Last of the Giants. Grand Rapids, MI: Chosen Books, 3.

Oyeshola, D. (2005). Conflict and Context of Conflict Resolution. Ile Ife, Nigeria: Obafemi Awolowo University Press Limited.

Parsons, M.C. (2008). Acts. Grand Rapids, Michigan: Baker Academic.

Roney, K. (2005). The Book of Acts with a Spectacle. Greenwich, CT: Information Age.

Scales, P.C. (2010)Influence of Persecution. Westerville, OH: National Middle School Association.

Shipler, D.K. (1986). The Works of Christians in Regards to the Ongoing Persecution in Nigeria. New York, Times Books.

Wallace, J. (1982). The State of Christian Persecution in My World. Nashville, Tennessee: Broad man Press.

Whitefield, S.(2004).Moving Towards a Biblical Understanding of Persecution. Grand Rapids: Zondervan Publishing Company. 